\title{
Structure and Mechanical Properties of Aluminium Alloys AlSi10 and AISi5Mg
}

Jiří Machuta ${ }^{1}$, Iva Nová ${ }^{1}$, Pavel Kejzlar ${ }^{2}$

${ }^{1}$ Faculty of Mechanical Engineering, Technical University of Liberec, Studentská 2, 46117 Liberec 1, Czech Republic. E-mail: iva.nova@tul.cz,jiri.machuta@tul.cz

${ }^{2}$ Institute for Nanomaterials, Advanced technologies and Innovation, Technical University of Liberec, Studentská 2, 461 17 Liberec 1, Czech Republic. E-mail: pavel.kejzlar@tul.cz

The article presents the microstructure and mechanical properties of two types of aluminium alloys AISi10 and AISi5Mg. The structure and mechanical properties as a tensile test of two alloys AISi10 and AISi5Mg were studied and compared. Gravity casting is very good process for making complex mechanical parts of low density metals like aluminium alloys. Therefore our samples are prepared by gravity casting technology. Light metals have come to the forefront in the automotive industry and improved fuel economy. Therefore, we compared the AISi5Mg alloy with a commonly used alloy AISi10. This type of alloy AISi5Mg has excellent casting and technological properties (good machinability and corrosion resistance). We are engaged with the issue of the production of castings for the automotive industry, at our department the Department of Engineering Technology-Technical University of Liberec, many years. Currently, we are focusing on aluminium alloys, their metallurgy and crystallization conditions with minimal internal defects.

Keyword: Aluminium, Strength, Structure, Strain, Mechanical properties

\section{Acknowledgement}

This results was supported by institutional support 117/2200 project TU of Liberec.

\section{References}

[1] KEJZLAR, P., ŠVEC, M., MACAJOVÁ, E. (2014). The usage of BSE in scanning electron microscopy. Manufacturing Technology, Vol. 14, No 3. pp. 333-336. ISSN 1213-2489.

[2] ROUČKA, J. (2004). Metalurgie neželezných slitin. 1. vyd. Brno: Akademické nakladatelství CERM, s.r.o. Brno, 2004. 148 s. ISBN 80-214-2790-6.

[3] BORKO, K., TILlovÁ, E., CHALUPOVÁ, M. (2016). The Impact of Sr Content on Fe - Intermetallic Phase's Morphology Changes in Alloy AlSi10MgMn. In: Manufacturing Technology, Vol. 16 No 1. pp. 20-26. ISSN 12132489.

[4] Aluminium Rheinfelden [online]. [cit. 2017-08-29]. Available from: http://rheinfelden-alloys.eu/en/alloys/anticorodal/\#ac50

[5] MARTINOVSKÝ, M., MÁDL, J. (2016). The Effect of Different Modifiers in AlSi7Mg0.3 Alloy on Built-up Edge Formation in Machining. In: Manufacturing Technology, Vol. 16 No 1. pp. 173-178. ISSN 1213-2489.

[6] NÁPRSTKOVÁ, N., CAIS, J., INGLADI, M. (2016). Modification of AlSi9CuMnNi Alloy by Antimony and Heat Treatment and Their Influence on Tool Wear after Turning. In: Manufacturing Technology, Vol. 16 No 1. pp. 209-214. ISSN 1213-2489.

[7] ŠČURY, J., BOLIBRUCHOVÁ, D., ŽIHALOVÁ, M. (2016). Effect of Nickel on the Properties of the AlSi10MgMn Alloy with Increased Iron Content. In: Manufacturing Technology, Vol. 16 No 1. pp. 243-247. ISSN 1213-2489.

[8] ŽIHAlOVÁ, M., BOLIBRUCHOVÁ, D., CAIS, J. (2015). Microstructural Analysis of Nickel Influence in AlSi10MgMn Alloy with Increased Iron Level. In: Manufacturing Technology, Vol. 15 No 4. pp. 743-748. ISSN 1213-2489.

[9] SVOBODOVA, J. (2014). SEM and EDS Analysis Used in Evaluation of Chemical Pre-treatment Based on Nanotechnology, Manufacturing Technology, Journal for Science, Research and Production, October, Vol. 14, No. 3, ISSN 1213-2489.

[10] BATYŠEV, A. I. (1990). Crystallization of metals and alloys under pressure. 2nd Edition, Metallurgija, Moskva, (in Russia).

[11] MICHNA, Š., LUKÁČ, I., OČENÁŠEK a kol. (2005). Encyklopedie hliníku, Prešov, ISBN 80-89041-88-4, (in Czech). 